\title{
CLINICAL CHARACTERISTICS OF BENIGN PAROXYSMAL POSITIONAL VERTIGO (BPPV) IN PERIMENOPAUSAL WOMEN
}

\author{
Korsunskaya L.L.*, Meshcheryakova A.V. \\ Vernadsky Crimean Federal University, Crimea; \\ Medical Academy named after S.I. Georgievsky, department of Neurology and Neurosurgery, Crimea
}

The article presents the structural features of benign positional paroxysmal vertigo (BPPV) to gender differences in the comprehensive assessment of the epidemiology of vestibular dysfunction in women of perimenopausal period, allowing for flow of advanced reproductive disorders and medical background correction of dishormonal states.

Keywords: vestibular dysfunction, BPPV, women, perimenopause.

Variety of neurological manifestations during perimenopause is determined by the position of receptors to the reproductive steroids in all organs and systems of organism. Any dyshormonal states can cause disorders in the central nervous system, oversegmental and segmental parts of the vegetative nervous system and result in the development of climacteric syndrome, vascular pathology and other visceral disorders, including vestibular dysfunctions [2, 5]. Steroids influence effects on the whole central nervous system on the whole and on the vestibular structures. In particular, directed at the modulating of morphological, plastic and physiological properties (neuronal excitability, energy production in mitochondrions, synthesis, release and transport of neurotransmitters). This largely depends on the stage of ageing process of the reproductive system, individual peculiarities of sex steroid secretion, type of dyshormonal disorders and time of their formation as well as premorbid somatic status of a woman, her quality of life and social activity. Permanent homeostasis disorder during perimenopausal period is evident through the different clinical signs and syndromes as a result of imbalance of somatic, neurohumoral and neurotransmitter systems of the organism [1, 9]. The urgency of many-sided interdisciplinary approach to the study of features of vestibular dysfunction in women of perimenopausal period is caused by the necessity of integrative complex approach to the study of interconnection of dyshormonal states appearing in the certain periods of reproductive system aging and vertigo syndrome of different genesis $[1,4]$.

One of the main neurological symptoms in women of this age category is vertigo symptom arisen within vestibular syndrome and characterized with visual and spatial disturbances, vegetative disorders of different manifestation degree as well as postural instability and vertigo itself. Meanwhile complaint of vertigo may be the main and sometimes the only symptom of vestibular dysfunction, whose nature can be different [3]. Vertigo division into vestibular (real, systemic) and nonvestibular (uncertain, nonsystemic) is clinically important $[4,6]$. Nonvestibular dizziness, is thought to be a feeling of disturbed or weakened spatial orientation without imaginary or distorted sense of movement $[1,7]$. Nonvestibular dizziness may occur under different somatic diseases including: climacteric syndrome, lipothimia, orthostatic hypotension, psychiatric diseases, syncopal syndrome, drug intoxication, hypoglycemia, some diseases of cardiovascular system, blood diseases, diseases of respiratory apparatus etc. $[1,12]$. Nonvestibular dizziness applies equally to imbalance and incoordination (hypotaxia) manifested through the impaired walking function of different etiology [11]. The most important variant of nonsystemic dizziness is considered to be the psychogenic dizziness clinically apparent in the context of worried, depressed and neurotic states against the background of the evident emotional experience and stress factors. In particular, dyshormonal disturbances in most women of late reproductive period apply to them [8]. Many authors admit psychogenic dizziness to be most prevalent. A famous German neurologist T. Brandt, occupied with the problem of dizziness, singled out "psychogenic postural instability" or "postural phobic instability" as an independent diagnosis [11]. Such patients haven't got any neurologic or somatic causes of dizziness, but there are these or other psychoemotional disorders. Staying at home, in habitual atmosphere the

*e-mail: neurocrimea@mail.ru 
patients don't feel discomfort. But when they get into a situation that demands the heightened coordination of movements the patients start feeling dizzy. The causes of this kind of dizziness are mostly combined: there is a disease of vestibular apparatus in combination with anxious or phobic disorder in the patient's anamnesis, but as a whole, this state makes the semblance of vascular pathology of the brain [7, 11, 13].

Mistakes in the diagnoses of such patients promote chronic diseases and their early disability. Besides, they can create the illusion of positive influence of many drugs (placebo effect) and methods of treatment $[2,7]$. Vestibular dysfunction can be manifested through real vestibular vertigo caused by the lesion of central parts (vestibular nuclei of the brainstem, vestibular bonds and vestibular centers of brain) or peripheral parts (vestibular nerve and labyrinth) of vestibular analyzer. The illusion of the movement of your own body or surrounding objects is typical for vertigo [13]. The lesion of the peripheral part of vestibular analyser is mostly caused by benign paroxysmal positional vertigo, Meniere's disease and vestibular neuronitis. Perilymphatic fistula, bilateral vestibulopathy, labyrinthitis and neurinoma of vestibulocochlear nerve occur more seldom $[4,15]$.

The considerable part of all the cases of vestibular vertigo is benign paroxysmal positional vertigo (BPPV). In spite of BPPV occurrence, its diagnostics is rather complicated. In most cases positional vertigo is of idiopathic type. However sometimes people with associated metabolic disorders (urolithiasis, dislipedemie, cholelithiasis) or after craniocerebral injury suffer from it [13]. Up to 1 minute of short dizzy spells accompanied by horizontal or horizontal and rotatory nystagmus can be provoked by the change of head position most often in the morning after sleep or at night $[1,11,15]$. Pathogenetic reason of the disease is ductlithiasis that causes the lymph flow disturbance in one of the semicircular ducts (usually in the posterior semicircular duct) resulting in the heightened sensitivity of vestibular receptors to the change of body position. In order to prove the diagnoses, different methods confirming the involvement of semicircular ducts are used, such as Dix-Hollpike's test [1, 6]. Some patients with BPPV suffer from vomiting and instability which can remain even after the full termination of the spell. A lot of patients worry about falling. Anxious disorders and depression appear. All these things reduce the quality of life and their social activity [13].

In the German epidemiologic study of Breven M. et al. (2007) it is informed that $86 \%$ of the interviewed patients with BPPV have psychosocial restrictions to a considerable extent $[10,14]$. These restrictions complicated a lot of daily activity of the patients and in most cases resulted in the growth of depression and anxious states. BPPV is the age-dependant pathology. Disease debut is usually observed at the age of 50; It is seven times as widespread for people over 60 [15]. BPPV is very high among elderly patients - up to $68 \%$ [6, 12]. BPPV peak falls at the age of 70-78 years. By natural cognation the probability of this disorder is five times as high [(Burlamaqui et al., 2006]. Annual BPPV rate makes $0.6 \%$, and it was informed in some research papers that women suffer from it more often than men; In most of other studies gender difference wasn't observed [9].

Studies of BPPV structural features showcasing gender differences have yet to published no special studies (in accordance with the information in the papers studied by us) evaluating fully the structure of peripheral vestibular dysfunction in different perimenopausal periods having taking into account the variety of causes of their onset of hormonal correction of late reproductive disorders. Thus there is a necessity to a more detailed study of this problem.

The purpose of this research is to evaluate the features of structural distinctions in the epidemiology of benign paroxysmal positional vertigo.

Materials and methods. We made clinical and neurologic examination of 380 women of perimenopausal period, age 44 to 51 (the average age made $47.5 \pm 2.4$ years) who complained of vertigo of different genesis. Out of them, there were 284 $(74.7 \%)$ women with dizziness of nonvestibular nature, $96(25.3 \%)$ - with real vestibular vertigo.

The insertion criterion for the further examination of patients was clinical and neurologic data about real vestibular dysfunction. The exclusion criterion for the full investigation was the: 
atherosclerotic stricture formation of extracranial and intracranial great vessels, vascular malformations and aneurism, cerebrovascular accidents in anamnesis, hypertension, coagulopathy and ischemic heart disease, new formations found in women under the data of ultrasound duplex scanning of extracranial and intracranial great vessels.

96 women with real vestibular dysfunction were chosen after the primary screening. By means of direct randomization method all patients were distributed in groups depending on the stage of perimenopausal period and the type of medical correction of advanced reproductive disorders. The first group consisted of the women (32 patients) with vestibular dysfunction who took betahistine against the background of hormonal agents containing mainly estrogens. The second group consisted of the women (30 patients) with vestibular dysfunction who took betahistine against the background of hormonal agents containing mainly progestins. Control group consisted of the women with vestibular dysfunction who took betahistine without hormonal therapy - 34 patients.

At the beginning of the examination the women forming the control group and two other groups were comparable by sex, age, arterial pressure, risk factors, associated gynecological pathology and real vestibular dysfunction.

Clinical evaluation of the patients state included the examination of somatic, neurologic status of patients with the objectification of disorders with the help of questioners modified by us. These questioners helped to evaluate both qualitatively and quantitatively the features of vestibular dysfunction syndrome in the women of perimenopausal period: Hamilton scale of anxiety, EEV European scale, vestibular dysfunction scale. Clinical and biochemical blood tests, immunohistochemical examination of endometrium scrape (by indications) were made. Ultrasound duplex scanning of extracranial and intracranial great vessels of the head was made for all patients. MRI-scan of the brain and cervical spine was made for a number of patients.

Results and discussion. We examined patients with vestibular dysfunction and analyzed vestibular passport of 96 women taking part in the examination. The certain detected regularities with regard to real vestibular vertigo allowing for "hormonal continuum" of women are presented in Table 1.

Table 1.

Structure of occurrence of different forms of vestibular dysfunction in women of perimenopausal period

\begin{tabular}{|l|l|l|l|l|}
\hline & Total & $\begin{array}{l}\text { Control } \\
\text { group }\end{array}$ & $\begin{array}{l}\text { Taking } \\
\text { estrogenes }\end{array}$ & $\begin{array}{l}\text { Taking } \\
\text { progesterones }\end{array}$ \\
\hline Vestibular dysfunction & $96(25.3 \%)$ & 34 & 32 & 30 \\
\hline $\begin{array}{l}\text { Peripheral vestibular } \\
\text { disfunction }\end{array}$ & $\mathbf{6 8 ( 1 7 . 8 \% )}$ & & & \\
\hline BPPV & $49(12.8 \%)$ & $18(\%)$ & $16(\%)$ & $15(\%)$ \\
\hline Vestibular neuronitis & $3(1.3 \%)$ & $1(\%)$ & $2(\%)$ & $0(\%)$ \\
\hline Bilateral vestibulopathy & $2(0.5 \%)$ & $0(\%)$ & $1(\%)$ & $2(\%)$ \\
\hline Meniere's disease & $13(3.4 \%)$ & $5(1.3 \%)$ & $3(0.7 \%)$ & $4(1.0 \%)$ \\
\hline Vestibular paroxysmia & 0 & 0 & 0 & 0 \\
\hline Perilymph fistula & $1(0.2 \%)$ & 0 & 0 & $1(0.2 \%)$ \\
\hline $\begin{array}{l}\text { Viral or bacteriological } \\
\text { labyrinthitis }\end{array}$ & 0 & 0 & 0 & 0 \\
\hline $\begin{array}{l}\text { Central vestibular } \\
\text { dysfunction }\end{array}$ & $\mathbf{2 8 ( 7 . 3 \% )}$ & & & \\
\hline Vestibular migraine & $18(4.7 \%)$ & $13(3.4 \%)$ & 0 & $1.3 \%)$ \\
\hline $\begin{array}{l}\text { Chronic vertebrobasilar } \\
\text { insufficiency }\end{array}$ & $9(2.3 \%)$ & $3(0.7 \%)$ & $4(1.0 \%)$ & $3(0.7 \%)$ \\
\hline Craniovertebral anomalies & $1(0.2 \%)$ & 0 & 0 & $1(0.2 \%)$ \\
\hline Barré-Lieou syndrome & $2(0.5 \%)$ & $1(0.2 \%)$ & 0 & $1(0.2 \%)$ \\
\hline $\begin{array}{l}\text { Consequences of closed } \\
\text { traumatic brain injury }\end{array}$ & $5(1.3 \%)$ & $2(0.5 \%)$ & $2(0.5 \%)$ & $1(0.2 \%)$ \\
\hline Dissipated sclerosis & $2(0.5 \%)$ & $2(0.5 \%)$ & 0 & 0 \\
\hline TIA & $1(0.2 \%)$ & 0 & 0 & $1(0.2 \%)$ \\
\hline
\end{tabular}


In context of the results we received it should be noted that in the structure of peripheral vestibular dysfunction BPPV makes rather large percent $12.8 \%$ among the women of perimenopausal period. It should be observed that we received a considerable number of women with BPPV in all three groups irrespective of correction methods of advanced hormonal disorders. The age of women in our examination fluctuated between 44 and 50 (average age made 46.5 \pm 2.5 ). In this connection it can be noted that these indices are a bit different from the well-known positions for the reason that under statistic data the age-dependant BPPV increase is observed in patients over 50. The results gathered from our work testifies the earlier debut of BPPV in women.

The confirmation of this conclusion can be demonstrated with comparative analysis of structure of vestibular disorders set forth in other examinations. In accordance with data of the most foreign authors about $8 \%$ of all vestibular disorders falls on BPPV. But in the structure of lesion of peripheral part alone of the vestibular analyser there is $17-35 \%$ of cases in patients at the age of 50 and over $[4,8]$. A number of patients with BPPV with no account taken of gender differences under L.A. Dziak data makes approximately $17 \%$, comparable indices are

\section{REFERENCES}

1. Bogdanov E.I. Vestibular syndrome by stroke. / E. I. Bogdanov // Neurologic Journal. - 2011 - No 3 - P. 42- 52. 2. Veselago O.V. Vertigo in neurologic practice / O.V. Veselago// Doctor in charge. - 2010. - No 5. - P. 15-16

3. Gabieva N.N. Morphofunctional state of heart and features of pathogenesis of arterial hypertension in women of postmenopausal period / N.N. Gabieva, A.B. Bakhshaliev // Ukrainian medical journal. - 2010 - No 6. - P. 29- 30.

4. Zamergrad M.V. Vestibular vertigo / M.V. Zamergrad // Neurology, Neuropsychiatry Psychosomatics. - 2009. No 1. - P.14- 18.

5. Malichenko S.B. Femoston Vasoactive effects in women of metabolic postmenopausal syndrome / S. B. Malichenko, E. P. Amyalyeva, L.B. Lazebnik // Clinical Medicine. 2000. -No 6. - P.10- 11.

6. Meshcheryakova A.V. The epidemiology of vestibular dysfunction in women with perimenopausal period / L.L. Korsunska, A.V. Meshcheryakova // Crimea Journal of Experimental and Clinical Medicine. - 2013. - Vol. 3. - No $1 ? 2$ (9 - 10). - P.14?17.

7. Saidova R.A. Modern principles of hormonal correction of menses disturbance in perimenopausal period/ R. A. given in papers of Brandt.

Conclusions: Such difference is believed to be caused by the fact that patients of both gender groups were included in most examinations mentioned above. Statistical divergences we received - the percentage increase of patients with BPPV among women - predetermine the dependence of the disease occurrence on gender. We think, this gender feature in BPPV structure is connected, first of all, with the dyshormonal factor in the late reproductive period in women. It is the hormonal dysfunction that underlies the change of water-electrolytic balance, endolymph $\mathrm{pH}$, metabolic imbalance of glucose and lipids and leads to degenerative changes of otolithic membrane.

Besides, the neuroactive role of reproductive steroids should be noted, directly modulating of physiological and neuroplastic properties of central nervous system as well as the availability of specific intracellular steroid receptors in cerebral cortex, limbic system, cerebellum, preoptic part of hypothalamus, brainstem, lower tuber of quadrigeminal plate, tonsil. The listed facts can also predetermine the data received by us about the increase of BPPV occurrence in women of late reproductive period compared to the average (typical) indices for the persons of this age category with no account taken of gender difference.

Saidova, S.G. Aleksonyan, E.V.Tropynina // Problems of gynecology. Obstetrics and Perinatology. - 2008. - V.7, No 4. - P.46- 52.

8. Baloh W. Benign positional vertigo: clinical and oculograpic features in 240 cases / W. Baloh, M. Robert [et al.] // J. Neurology. - 1987. - № 37. - P. 371-378.

9. Burkman R.T. The hormone continuum accrual of women's health benefits / J. Obstet, R.T. Burkman // Gynecol.-2001. - V.185. - P. 16-17.

10. Breven M. Epidemiology of benign paroxysmal positional vertigo: a population based study / Breven M. [et al.] // J NeurolNeurosurg Psychiatry. - 2007. - № 7. - Vol.78. P. 710-715.

11. Brandt T. Management of vestibular disorders / T.Brandt // J. Neurology. - 2000. - № 247. - P. 491-499.

12. Chobanian A.V. Seventh report of the Join National Committee on prevention, detection, evaluation and treatment of high blood pressure / A.V. Chobanian, G.I. Bakris, H.R. Black // J. Hypertens. - 2003. - V.42. - P. 1206-1252.

13. Kentala E. Vertigo in patients with benign paroxysmal positional vertigo/ E. Kentala[et al.]// Acta Otolaryngol 
Suppl. - 2000. - № 543. - P. 20-22.

14. Lirm E.S. The hormone continuum accrual of women's health / E.S. Lirm, A.M. Kauntz, S. Schnare, M. Taylor //
GynecolEndocrinol. - 2010. - V.46. - №2. - P.60-72.

15. Trinus K.F. Chornobyl vertigo. 10 years of monitoring / K.F.Trinus // Neurootology Newsletter. - 1996. - P.140-142.

XÜLASə

\title{
PERIMENOPAUZA DÖVRÜNDЭ QADINLARDA XOSXXSSЭLİ POZISIION PAROKSIZMAL BAŞGICOLLONMӘNIN (XPPB) KLINIIK XARAKTERISTIKASI
}

\author{
Korsunskaya L.L., Meşeryakova A.B. \\ V.I. Vernadski adına Krım federal universiteti, Krım; \\ S.I.QQeorgiyevski adına Tibb akademiyası, sinir xastaliklari kafedrası, Krım
}

Məqalədə xoşxassəli pozision paroksizmal başgicəllənmənin (XPPB) struktur xüsusiyyətləri təqdim edilmişdir. Tədqiqat zamanı perimenopauza dövründə qadınlarda vestibulyar disfunksiyanın epidemiologiyasının kompleks qiymətləndirilməsi kontekstində gender xüsusiyyətləri, gecikmiş reproduktiv pozulmaların gedişinin xüsusiyyətləri və dishormonal vəziyyətin medikamentoz korreksiya fonu nəzərə alınmışdır. Açar sözlər: vestibulyar disfunksiya, XPPB, qadınlar, perimenopauza.

\section{РЕЗЮМЕ}

\section{КЛИНИЧЕСКАЯ ХАРАКТЕРИСТИКА ДОБРОКАЧЕСТВЕННОГО ПОЗИЦИОННОГО ПАРОКСИЗМАЛЬНОГО ГОЛОВОКРУЖЕНИЯ (ДППГ) У ЖЕНЩИН В ПЕРИМЕНОПАУЗЕ}

\author{
Корсунская Л.Л., Мещерякова А.В. \\ ФГАОУ ВО «Крымский федеральный университет им. В.И.Вернадского», Крым \\ Медииинская академия имени С.И.Георгиевского», кафедра нервных болезней, Крым
}

В статье представлены структурные особенности доброкачественного позиционного пароксизмального головокружения (ДППГ) с учетом гендерных отличий в контексте комплексной оценки эпидемиологии вестибулярных дисфункций у женщин перименопаузального периода, особенностей течения поздних репродуктивных нарушений и фона медикаментозной коррекции дисгормональных состояний. Ключевые слова: вестибулярная дисфункция, ДППГ, женщины, перименопауза.

Redaksiyaya daxil olub: 05.10.2015

Çapa tövsiyə olunub: 26.10.2015

Rayçi: t.e.d. Hasənov R.L. 